\title{
DETERMINANTS OF CREDIT ACCESS AMONG SMALLHOLDER DAIRY FARMERS IN KINANGOP SUB-COUNTY, KENYA
}

\author{
Wadeya Lennox Ongwech ${ }^{1^{*}}$ \\ ${ }^{1}$ Department of Agricultural Biosystems and Economics, School of Agriculture and Biotechnology, \\ University of Kabianga, Kenya \\ Christopher Obel-Gor ${ }^{2}$ \\ ${ }^{2}$ Associate Professor, Department of Agricultural Economics and Agribusiness Management, \\ School of Agricultural and Food Sciences, Jaramogi Oginga Odinga University of Science and \\ Technology, Kenya
}

\author{
Otiende Millicent Adhiambo 3 \\ ${ }^{3}$ Department of Horticulture, School of Agriculture and Biotechnology, \\ University of Kabianga, Kenya.
}

"Corresponding Author: Wadeya Lennox Ongwech

Article DOI: https://doi.org/10.36713/epra5808

\begin{abstract}
Dairy farming plays a major role in the Kenyan agricultural sector as it is dominated by smallholder farmers who contribute approximately 80 per cent of the total milk production. In Kinangop Sub County, there are many credit service providers however, not all smallholder dairy farmers have benefited from such services, instead smallholder dairy farmers have continued to experience challenges such as limited access to financial services. This study therefore analyzed the determinants of credit access among smallholder dairy farmers in Kinangop Sub-County using a binary logistic regression model. Following this, the marginal effects of the predictor variables on the likelihood of accessing credit were estimated. A total of 230 respondents were sampled from a population of 35,840 smallholder dairy farmers using both stratified and simple random sampling techniques and both structured and semi structured questionnaires were used to collect data. The study adopted descriptive survey research design. Descriptive analysis revealed that majority: $59.57 \%$ of smallholder dairy farmers were males, $69.57 \%$ were married and had a mean age of 39.4 years. The average household size was 4 members per household. Formal schooling was also attained by the respondents, majority having an average of about 8 years of schooling. On average farmers had 2 dairy cattle per household, produced 341litres of milk per month and had 11 years of farming. The binary logistic regression analysis and the marginal effect calculation revealed marital status, years of schooling, savings frequency, dairy farming as a primary occupation, financial education, association membership and number of dairy cattle as the significant determinants of credit access. The study therefore concluded that there were significant determinants of credit access in the study area and recommended that formulating policies geared towards enhancing educational attainment of farmers would be vital in enhancing credit accessibility to farmers in the study area. There is also need for the Government and other stakeholders to encourage dairy farmers to join farmer based associations and eliminate stringent collateral barriers and bureaucracies that tend to discourage smallholder dairy farmers from accessing and participating in different credit schemes.
\end{abstract}

KEY WORDS: Credit access, determinants, smallholder dairy farmers, Kinangop Sub-County.

(C) 2020 EPRA ARER | www.eprajournals.com | Journal DOI URL: https://doi.org/10.36713/epra0813 


\section{INTRODUCTION}

Agriculture is a proven path to prosperity and no region in the world has developed a diverse modern economy without first establishing a successful foundation in Agriculture [1]. [2] posits that agricultural sector accounts for one third of global GDP. In Kenya, Agriculture contributes $24 \%$ of the GDP valued at approximately 342 billion. Further, the sector contributed $65 \%$ of export earnings and employed $70 \%$ of the population in rural areas [3] and [4]. Dairy sector in Kenya is rural based and contributes $14 \%$ of agricultural GDP, $40 \%$ of livestock sector GDP and (4-8)\% of total GDP [5]. Smallholder farmers are the main actors in the Kenyan dairy sub-sector producing up-to $80 \%$ of the total milk [6]. Dairy farming is majorly practiced in the Central, Rift valley and Coastal lowlands which offer favourable agro climatic conditions (ACZ) 1-4 [3]. There has been an increase in the livestock population in Kenya. [7] estimates that the Kenyan dairy population comprises: 14.1 million indigenous cattle and 3.4 million exotic cattle totaling to 17.5 million. This is approximately $27 \%$ of total livestock population in Kenya.

Previous studies attempted to determine the role of agricultural credit in enhancing farm household income, for instance [8] observed that credit access is crucial for improving farm profitability index and rural living in developing countries. [9] also conducted a study on access to micro credit and its impact on farm profits among rural farmers in Dry- land of Sudan and found credit users to be having higher level of profits than non-credit users. [10] also examined the effect of credit on farm profits in Tunisia and found elasticity of profits with respect to credit to be 0.20 and 0.04 for rationed and nonrationed farmers respectively and concluded that better access to credit would significantly improve farm profits for rationed farmers.

Despite the positive role played by credit towards enhancing agricultural incomes, access to credit is however, still inadequate in developing countries. [11] estimated agricultural credit in Kenya to be less than $10 \%$ of the total credit provided through the domestic financial system. [12] identified limited credit services as a major constraint clouding the Kenyan dairy sector. In Kinangop region, dairy farmers have continued to face challenges such as inadequate access to agricultural credit. which limits the competitiveness of the sector [13].

\section{MATERIALS AND METHODS}

\subsection{Study Area}

The study was conducted in Kinangop SubCounty located in Nyandarua County, Kenya. The site was selected due to the dominance of dairy farming as the main source of livelihoods.

\subsection{Research Design}

The study adopted descriptive survey research design since it allows for the application of descriptive statistical methods hence allowed for collection of data so as to test the set hypothesis [14]. Descriptive survey research design was therefore applied in order to obtain the current information in regards to the socio-economic profile of smallholder dairy farmers and to determine what exists with respect to the determinants of credit access in the study area.

\subsection{Population}

The population for this study constituted smallholder dairy farmers in Kinangop Sub County.

\subsection{Sampling Procedures}

The study adopted [15] approach in determining the sample size. According to [15], the sample size of a finite population is given by: $n=\frac{\mathrm{NC}^{2}}{\mathrm{C}^{2}+(\mathrm{N}-1) \mathrm{e}^{2}}$ Where: $\mathrm{n}=$ sample size, $\mathrm{N}=$ Study population, $\mathrm{C}=$ Coefficient of variation and $\mathrm{e}$ is the error term. This study used a coefficient of variation of 0.30 and a standard error of 0.02 so as to increase the sample size and minimize the error. As notes [15] if the population exceeds 10,000 , the standard error should lie between $(0.02 \leq e \leq 0.05)$ and the confidence interval should range from $(0.21 \leq \mathrm{C}$ $\leq 0.30)$ Therefore $n=\frac{35,840(0.30)^{2}}{(0.30)^{2}+(35,840-1)(0.05)^{2}}=$ $3,226 / 14=230$ Afterwards, both stratified and simple random sampling techniques were applied. In stratified sampling, the researcher used the sample frame to classify the smallholder dairy farmers on the basis of the wards that they come from. Each ward therefore 
formed a stratum. The researcher then randomly selected the final subjects in each stratum proportionately based on the sample size as illustrated in table 1.

\subsection{Analytical techniques}

The study adopted a binary logistic regression to test if there were significant determinants of credit access. A binary logistic regression model essentially determines the likelihood of an event occurring relative to the likelihood of an event not occurring; the effect of the independent variable is usually explained in terms of odds. Hence the dependent variable has a binary outcome ( $1=$ access to credit and
$0=$ otherwise) thereby making the model suitable for the study. The model was explicitly stated as: $y=\alpha+\beta_{1} G E+\beta_{2} A G E+\beta_{3} M S+\beta_{4} H H+\beta_{5}$ YOS $+\beta_{6}$ FS $+\beta_{7}$ EXP $+\beta_{8}$ SF $+\beta_{9}$ OFFinc $+\beta_{10}$ ONWT $+\beta_{11}$ FinEDU $+\beta_{12}$ AssnMBSHP $+\beta_{13}$ VA $+\beta_{14} \mathrm{PDN}+\beta_{15} \mathrm{DCTLE}+\beta_{16} \mathrm{DIST}+\varepsilon_{\mathrm{ij}} \quad 1$

$X_{i j s}=$ are the predictor variables of interest. (Gender, age, marital status, head of household, years of schooling, family size, farming experience, savings frequency, off farm income, ownership type, financial education, association membership, value addition practice, milk production levels, number of dairy cattle, distance to credit source), $\alpha$ and $\beta_{1} \ldots \beta_{16}$ are the structural coefficients of the model and $\varepsilon$ is the error term.

\begin{tabular}{|c|c|c|}
\hline \multicolumn{3}{|c|}{ Table 1. Illustration of Sample Size Determination } \\
\hline Geographical area/Ward & Population (P) & Sample size (P/T)n \\
\hline Engineer & 4,659 & 30 \\
\hline Njabini & 3,942 & 25 \\
\hline Magumu & 2,150 & 14 \\
\hline Nyakeo & 5,376 & 35 \\
\hline Murungaru & 6,093 & 39 \\
\hline Gedhabai & 4,301 & 27 \\
\hline Gadhara & 4,309 & 28 \\
\hline North Kinangop & 5,010 & 32 \\
\hline TOTAL (T) & $\mathbf{3 5 , 8 4 0}$ & $\mathbf{2 3 0}$ \\
\hline
\end{tabular}

Table 2. Description of the independent variables used in the binary logistic regression model

\begin{tabular}{lllc}
\hline Variable & Coding System & Category & Expected sign \\
\hline $\mathrm{X}_{1}=$ Gender & 1 if male, 0 if female & Dummy & $+/-$ \\
$\mathrm{X}_{2}=$ Age & Number of years & Continuous & + \\
$\mathrm{X}_{3}=$ Marital status & 1 if married, Otherwise 0 & Categorical & + \\
$\mathrm{X}_{4}=$ Head of household & 1 if yes, 0 if otherwise & Dummy & + \\
$\mathrm{X}_{5}=$ Years of schooling & Number of years & Continuous & + \\
$\mathrm{X}_{6}=$ Household size & Number of members & Continuous & + \\
$\mathrm{X}_{7}=$ Farming experience & Number of years & Continuous & + \\
$\mathrm{X}_{8}=$ Savings frequency & 1 if save regularly, 0- otherwise & Dummy & + \\
& & & \\
& & & + \\
$\mathrm{X}_{9}=$ Main employment & farming, $4-$ others businesses & Categorical & + \\
$\mathrm{X}_{10}=$ Off farm income & Kenyan shillings & Continuous \\
$\mathrm{X}_{11}=$ Ownership & 1 if sole trader, 0 if Partnership & Dummy & $+/-$ \\
$\mathrm{X}_{12}=$ Financial education & 1 if member, 0 if Otherwise & Dummy \\
$\mathrm{X}_{13}=$ Association & 1 if member, 0 if otherwise & Dummy \\
$\mathrm{X}_{14}=$ Value addition & 1 if yes, otherwise 0 & Dummy \\
$\mathrm{X}_{15}=$ Total land size & Number of hectors & Continuous \\
$\mathrm{X}_{16}=$ Dairy cattle HH & Number of cattle & Continuous \\
\hline
\end{tabular}

(c) 2020 EPRA ARER | www.eprajournals.com | Journal DOI URL: https://doi.org/10.36713/epra0813 
EPRA International Journal of Agriculture and Rural Economic Research (ARER)- Peer-Reviewed Journal Volume: 8 | Issue: 5| November 2020| Journal DOI: 10.36713/epra0813|Impact Factor (SJIF): 7.367| ISSN: 2321 - 7847

\section{RESULTS AND DISCUSSIONS}

\subsection{Socio-economic profile of the respondents}

Table 3. Distribution of respondents according to their socio-economic profiles

\begin{tabular}{|c|c|c|}
\hline Variable & Frequency & Percentage \\
\hline \multicolumn{3}{|l|}{ Gender } \\
\hline Male & 137 & 59.57 \\
\hline Female & 93 & 40.43 \\
\hline \multicolumn{3}{|l|}{ Age Distribution } \\
\hline$\leq 30$ & 46 & 20 \\
\hline $31-40$ & 90 & 39.1 \\
\hline $41-50$ & 69 & 30 \\
\hline Above 50 & 25 & 10.87 \\
\hline \multicolumn{3}{|l|}{ Marital Status } \\
\hline Single & 3 & 13.48 \\
\hline Married & 160 & 69.57 \\
\hline Widow & 20 & 8.7 \\
\hline Divorced & 13 & 5.65 \\
\hline Widowed & 6 & 2.61 \\
\hline \multicolumn{3}{|l|}{ Years of Schooling } \\
\hline 0 & 18 & 7.83 \\
\hline $1-8$ & 116 & 50.43 \\
\hline $9-16$ & 96 & 41.74 \\
\hline \multicolumn{3}{|l|}{ Household Head } \\
\hline Yes & 166 & 72.17 \\
\hline No & 64 & 27.83 \\
\hline \multicolumn{3}{|l|}{ Family size } \\
\hline $1-5$ & 187 & 81.3 \\
\hline $6-10$ & 36 & 15.65 \\
\hline $11-15$ & 7 & 3.04 \\
\hline \multicolumn{3}{|l|}{ Source of Labour } \\
\hline Family & 148 & 64.35 \\
\hline Hired & 56 & 24.35 \\
\hline Both & 26 & 11.3 \\
\hline \multicolumn{3}{|l|}{ Main employment } \\
\hline Formal employment & 36 & 15.65 \\
\hline Informal employment & 29 & 12.61 \\
\hline Dairy farming & 115 & 50 \\
\hline Other businesses & 50 & 21.74 \\
\hline
\end{tabular}


The results presented in table 3 established that majority, $59.57 \%$ of the respondents were males, as compared to $40.43 \%$ who were females. The findings concur with that of [16] which also revealed a greater percentage of smallholder dairy farmers in rural areas to be males. It can therefore be inferred that most smallholder dairy farming enterprises in the study area are managed by males. This could be explained by the fact that more males in developing countries have greater access to resources at the household level than females [17] and as such are able to engage in more income generating activities such as dairy farming.

Majority of the respondents $39.13 \%$ belonged to the age group of between (31-40) years, $30 \%$ of the respondents were aged between (41-50) years, 20\% having less than 30 years while $10.87 \%$ were above 50 years (table 3). Similar results were revealed by a study conducted by [18] and [16]. Based on their findings, majority of rural farmers were in the middle class age hence considered as active working age category.

To establish marital status of the respondents, findings showed that about $70 \%$ of the sampled dairy farmers were married while those not married (single, widow, widowed, divorced) were approximately $30 \%$ (table 3 ). This indicate that majority of the respondents were married. A study conducted by [19] also revealed a greater percentage of livestock farmers in Nigeria to be married and attributed it to the greater demand for food and nutrition security that comes as a result of being married.

Majority of the respondents, $50.43 \%$ had between (1-8) years of schooling, $41.74 \%$ had between (9-16) years of schooling with only $7.83 \%$ having not attained formal schooling (table 3). An indication that most dairy farming enterprises in the study area are managed by people with relatively low years of schooling. The implication for this is that, sustainable dairy management practices would hardly be observed since dairy farmers need good education on dairy farming practices for them to be able to harness all available resources to the advantage of production. Meanwhile, credit service providers would be attracted to dairy enterprises that are sustainable as it will enhance loan repayment.

Majority of the dairy farmers, $72.17 \%$ were household heads while $27.83 \%$ were nonhousehold heads (table 3). This implies that household heads were more aggressively involved in dairy farming than non-household heads.

To establish the household sizes of the respondents, the findings revealed that majority, $81.30 \%$ had a household size of between (1-5) members, $15.65 \%$ had a household size of between (6-10) members and only 3.04\% having household sizes of between (11-15) members (table 3). This is an indication of smallholder household sizes. The implication for this is that there could be overreliance of hired labour as a supplement for family labour which might be a drain to the profits.

Majority, $50 \%$ of the sampled households practiced dairy farming as their primary occupation (table 3). An indication that dairy farming is the main economic activity of farmers in the study area. Consequently, $21.74 \%$ primarily engaged in other businesses, $12.6 \%$ cited informal employment as their primary occupation while $15.65 \%$ \% cited formal employment as their primary occupation. These results suggest that secondary occupation is critical in generating off farm income for smallholder dairy farmers.

\subsection{Access to credit, credit sources and repayment attitude of the respondents}

Table 4 Distribution of respondents based on access to credit, credit sources and repayment attitude

\begin{tabular}{lll}
\hline Variable & Frequency & Percentage \\
\hline Obtained Credit & 79 & 34.35 \\
Yes & 151 & 65.65 \\
No & &
\end{tabular}

\section{Credit source}

$\begin{array}{lll}\text { Commercial banks } & 11 & 4.78 \\ \text { Dairy cooperatives } & 25 & 10.87\end{array}$




$\begin{array}{lll}\text { NGOs } & 5 & 2.17 \\ \text { Govt. credit schemes } & 7 & 3.04 \\ \text { SHGs } & 11 & 4.78 \\ \text { Professional money lenders } & 1 & 0.43 \\ \text { Friends and relatives } & 5 & 2.17 \\ \text { SACCOs } & 1 & 0.43 \\ \text { Mobile platforms } & 13 & 5.65 \\ \text { Never obtained credit } & 151 & 65.65 \\ \text { Repayment attitude } & & \\ \text { Constraint } & 20 & 8.7 \\ \text { Otherwise } & 59 & 25.65 \\ \text { No responses } & 151 & 65.65\end{array}$

Majority, $65.65 \%$ of the respondents never obtained credit (table 4). The respondents cited that inadequate collateral, limited information on different credit products offered by credit service providers, inadequate guarantorship and lack of interest were the main factors that constrained their ability to access credit. Only $34.35 \%$ of the respondents obtained credit from different sources. This therefore implies that majority of smallholder dairy farmers were credit constrained.

Majority, $10.87 \%$ of the respondents obtained credit from dairy cooperatives, $4.78 \%$ obtained credit from commercial banks, $2.17 \%$ from NGOs, offering microfinance services to farmers, $3.04 \%$ from Government credit schemes, $4.78 \%$ from SHGs, $0.43 \%$ from professional money lenders, $2.17 \%$ from friends and relatives, $0.43 \%$ from other SACCOs and $5.65 \%$ from mobile money platforms (table 4 ). This implies that semi-formal credit sources such as dairy cooperatives, NGOs,

Government credit schemes were highly preferred due to farmer friendly loan products. Moreover, some of the informal credit providers such as dairy cooperatives take the lead in marketing the milk on behalf of farmers hence attracting most farmers. Informal sources such as self-help groups, friends and relatives and professional money lenders was second in preference due to their relatively lower interest rates in comparison to formal credit sources even though loan security is not guaranteed. The formal financial sources was least in preference due to rigorous pre-lending bureaucracies as well as the stringent collateral requirements that tends to lock out most smallholder dairy farmers from accessing credit from formal credit sources.

Further results shows that $8.7 \%$ of the respondents perceived loan repayment as a constraint due to inadequate grace period, loan inadequacy as well as shifting the loan purpose to non-farm activities. Majority, $25.65 \%$ had a positive attitude towards loan repayment and found it easy to repay their outstanding loan balances. $65.65 \%$ however, did not give their responses since they never obtained credit. The majority cited loan adequacy, flexible repayment and availability of top-ups as some of the factors that enhanced their loan repayment ability (table 4).

\subsection{Credit attributes of respondents}

Table 5: Distribution of respondents according to credit attributes that influenced source preferences

\begin{tabular}{lll}
\hline Variable & Frequency. & Percentage \\
\hline Source preference & 38 & 16.52 \\
No collateral barriers & 9 & 3.91 \\
Financial training & 16 & 6.96 \\
Technical training & 7 & 3.04
\end{tabular}

(C) 2020 EPRA ARER | www.eprajournals.com | Journal DOI URL: https://doi.org/10.36713/epra0813 


\begin{tabular}{lll} 
No bureaucracies & 2 & 0.87 \\
Low interest rates & 5 & 2.17 \\
Flexible repayment & 1 & 0.43 \\
Possibility of top ups & 1 & 0.43 \\
\hline
\end{tabular}

Table 5 presents the attributes that influenced the credit source preferences of smallholder dairy farmers in the study area. From the table it is apparent that smallholder dairy farmers preference for different credit sources was influenced by collateral requirements, availability of financial education, availability of technical training on dairy farming, reduced interest rates, reduced bureaucracies, reduced loan processing fee, flexibility in loan repayment and possibility of top-ups. The results

\subsection{Summary statistics for continuous variables}

Table 6. Descriptive summary of various continuous variables among smallholder dairy farmers in Kinangop Sub County

\begin{tabular}{lllll}
\hline Variable & Mean & Std. Dev. & Min & Max \\
\hline Age & 39.44 & 8.718 & 22 & 59 \\
Farming Experience & 11.41 & 4.477 & 2 & 18 \\
Years of schooling & 7.635 & 4.179 & 0 & 16 \\
Family size & 4.318 & 2.502 & 0 & 15 \\
Distance to credit source & 2.689 & 1.940 & 0 & 11 \\
Dairy cattle & 2.482 & 1.435 & 1 & 10 \\
Milk production & 341.13 & 201.92 & 120 & 1200 \\
\hline
\end{tabular}

Total observations $(\mathbf{N})=\mathbf{2 3 0}$

Table 6 above presents a descriptive summary of the socio-economic profiles of smallholder dairy farmers in the study area. The respondents had a mean age of 39.5 years with a minimum age of 22 years and a maximum age of 59 years an indication that most of the dairy enterprises in the study area are being managed by relatively young and active members of the society. On average respondents had 11.4 years of farming with a minimum of 2 years and a maximum of 18 years. Expectedly, the more years of farming the greater the management competitiveness since experienced farmers are more able to manage their dairy farming enterprises professionally. Cases of feed, disease and marketing management could easily be handled by experienced farmers.

On average respondents recorded 7.6 years of schooling with the highest having 16 years of schooling. This means that majority of indicate that relaxation of collateral barriers was a key attribute of credit source preference as it had the highest percentage of $16.52 \%$, second to it was technical training which had a percentage of $6.96 \%$, followed by financial training with a percentage score of $3.91 \%$, reduced loan processing fee with a percentage of $3.04 \%$, reduced interest rates with a percentage of $2.17 \%$, absence of bureaucracies with a percentage of $0.87 \%$ while flexible repayment and possibility of top-ups having a percentage of $0.43 \%$ each. smallholder dairy farms were managed by people with relatively low years of schooling. The mean family size was 4 members per household with the largest household having 15 members hence most households were smaller in number. As such, dairy farmers might consider alternative sources of labour which might be a drain to profits. This explains why most smallholder farming enterprises collapse due to inability to meet their current obligations.

The mean distance to credit source was 2.7 $\mathrm{km}$ with the least distance being zero $\mathrm{km}$. This is attributed to the fact that lenders who embraced the digital lending platforms gave borrowers easy time in loan application and disbursement since borrowers are able to access credit without necessarily travelling to the premises of their lenders. On average, respondents had 2 dairy cattle with the least having only one cattle and the highest having 10 dairy cattle. The low

(C) 2020 EPRA ARER | www.eprajournals.com | Journal DOI URL: https://doi.org/10.36713/epra0813 
number of dairy cattle could be as a result of land fragmentation which diminishes portions allocated for forage production and grazing, unreliable and unpredictable rainfall patterns which increases the risk of keeping more cattle, high cost of farm inputs such as drugs, artificial insemination and medication which could also discourage smallholder dairy farmers from increasing their herds of dairy cattle.

\subsection{Results from the binary logistic regression model and the marginal effect calculation.}

Table 7: Summary results from binary logistic regression analysis and the marginal effect calculation

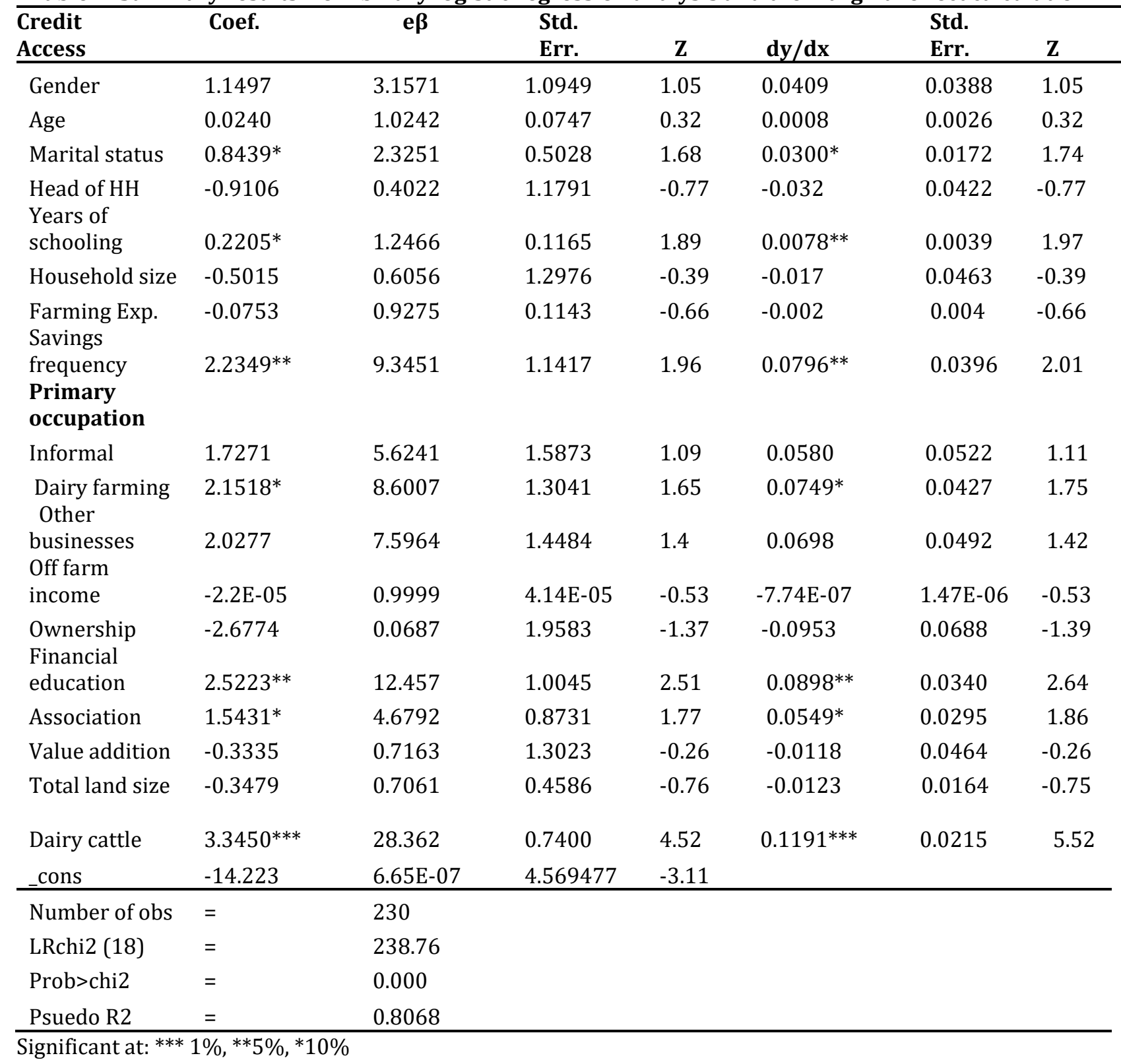

From the empirical estimation of the binary logistic regression model, 10 out of 16 variables were consistent to a priori expectation. 6 variables however, did not have the hypothesized signs. Seven variables; Marital status, years of schooling, savings frequency, dairy farming, financial education, association membership and dairy cattle of households significantly influenced credit access. The marginal effect calculation also revealed (marital status, years of schooling, savings frequency, dairy farming, financial education, association membership and dairy cattle of households as significant factors 
influencing credit access. The model has a Pseudo R2 value of 0.8068 indicating that about $80.68 \%$ of the variation in the dependent variable is explained by the predictor variables. This indicates a good fit. The computed Chi square of 238.76 which was significant at $(P<0.01)$ demonstrates the overall significance of the independent variables in predicting the response variable.

Marital status was positive and significant at $90 \%$ confidence interval $(p<0.1)$ implying that married households or those with counterparts are 2.33 times more likely to obtain credit than non-married households. The marginal effect results indicate that farmers who are married have a higher likelihood of obtaining credit by 0.02 than non - married farmers. [20] also presented similar results. This implies that there is high preference for disbursing credit to married households since they can easily co-guarantee each other hence overcoming the guarantorship requirements.

Years of schooling had a positive coefficient which was significant at $90 \%$ confidence interval $(p<0.1)$ implying that an additional increase in formal education increases the odds in favor of credit access by 1.25 . The marginal effect calculation was however significant at $95 \%$ confidence interval $(p<0.05)$ implying that an additional increase in years of schooling increases the likelihood of obtaining credit by 0.01 . [21] also revealed years of schooling as a significant factor influencing access to credit. Educated farmers are taken into confidence by credit providers since they are considered as being well informed with current knowledge that is essential in enhancing productivity. And as such, they are mostly at the forefront in different rural development programs targeting farmers. Other researchers such as [17] and [22] also observed that being educated enhances the likelihood of credit access.

Saving frequency was positive and significantly related to credit access at 95\% confidence interval $(p<0.05)$ implying that farmers who regularly save are 9.35 times likely to obtain credit than farmers who are non regular savers. Based on the marginal effect calculation, the predicted probability of obtaining credit is 0.08 greater for regular savers than for non - regular savers. Savings are considered as a form of security by credit providers hence regular savers are perceived to be more credit worthy.

Dairy farming had a positive coefficient which was significantly related to credit access at $90 \%$ confidence interval $(p<0.1)$, an indication that engaging in dairy farming as a primary occupation enhances access to credit. Hence farmers who primarily engaged in dairy farming were 8.06 times more likely to obtain credit than farmers who were in formal employment. Based on the marginal effect calculation, the predicted probability of obtaining credit was 0.07 greater for farmers whose primary occupation was dairy farming than for farmers who were in formal employment.

Financial education was positive and significantly related to credit access at $95 \%$ confidence interval $(p<0.05)$. Farmers who received financial training were 12.46 times more likely to obtain credit than farmers who never received financial training. Based on the marginal effect calculation, the predicted probability of obtaining credit was 0.09 greater for farmers who received financial training than for farmers who never received financial training. This could be attributed to the fact that training interventions impart new knowledge and skills to farmers which enhances their management competencies. As notes [23] managerial competitiveness is one of the internal factors influencing credit access among SMEs since they are able to make informed decisions geared towards optimizing returns. Financially literate farmers are able to plan and document their farming activities with ease.

Association membership had a positive coefficient which was significantly related to credit access at $(p<0.01)$. This implies that farmers belonging to association(s) were 4.68 times more likely to obtain credit than farmers who never belonged to any association(s). Based on the marginal effect calculation, members of associations have a higher likelihood of accessing credit by 0.03 than non-association members. [21] also revealed membership to a Farmer Based Organization 
as a significant factor influencing credit access hence the results from this study could be attributed to the fact that associations create an avenue where farmers can easily seek assistance and support from different credit providers. [17] also noted that being a member of association(s) enhances the credit access status of farmers since association membership serve as one of the key requirements by credit providers dealing with self-help groups.

Number of dairy cattle was positive and significant at $99 \%$ confidence interval $(p<0.01)$ implying that an additional increase in number of dairy cattle increases the odds in favor of credit access by 33.62. From the marginal effect calculation, an additional increase in dairy cattle of farmers increases the likelihood of accessing credit by 0.12 [24] reported a positive significant influence of firm size on credit access. [21] also found similar results and reported that large farms are less likely to default hence taken into confidence by credit providers.

\section{CONCLUSION}

From the study, factors such as marital status, savings frequency, financial education, association membership, dairy cattle of household and years of schooling were critical in enhancing access to credit. Thus, for more smallholder dairy farmers to obtain credit, governments and other stakeholders such as non-governmental organizations, commercial banks, micro-finance institutions, dairy cooperatives among others should initiate and implement financial training programs to smallholder dairy farmers, encourage smallholder dairy farmers to join farmer based associations or other associations, eliminate stringent collateral barriers and bureaucracies that tend to discourage smallholder dairy farmers from accessing and participating in different credit schemes, enhance educational attainment of farmers through establishing adult literacy training centers, conduct technical training to dairy farmers with the aim of encouraging expansion of farm sizes and adoption of sustainable dairy husbandry practices in smallholder dairy farming systems. Such interventions will enhance access to credit. There is also need to come up with stringent loan monitoring mechanisms to ensure that the loans disbursed are not shifted to non-farm activities. This can be done through offering post loan education as well as intensifying the interactions between the credit officers and the clients.

\section{Funding}

The author (s) received no financial support for the research, authorship, and/or publication of this article.

\section{Consent for Publication}

The Authors accepts and consents to publish the manuscript.

\section{Conflict of Interest Statement}

The authors declare no conflicts of interest.

\section{Acknowledgements}

The authors acknowledge the cooperation from the Kinangop Sub County Livestock Production Office who provided the relevant information needed for the study. We also appreciate all smallholder dairy farmers who took part in the study.

\section{REFERENCE}

1. Africa Agriculture Status Report. (2019). The hidden middle: A quiet revolution in the private sector driving Agricultural transformation.

2. International Development Agency. (2019). Kenya Economic Update; Unbundling the Slack in Private Sector Investment. $\left(19^{\text {th }}\right.$ Ed).

3. Ministry of Livestock Development MoLD. (2010). Kenya National Dairy Master Plan: A sustainable analysis of the Kenyan dairy sub sector, Nairobi, Kenya.

4. Njauri, D. M. G., Gichangi, E. M., Gatheru, M., Nyambati, E. M., Ondiko, C. N., Ndungu, K. W., Kiiya, W. W., Kute, C. A. and Ayako, W. (2016). A comparative analysis of livestock farming in smallholder mixed crop-livestock systems in Kenya. Livestock Research for Rural Development. 28 Article 66. Retrieved March

2019.fromhtts://www.lrrd.org/lrrd28/4/njar280 66.html

5. Corne, J. R., Bookline, O. B., Jan van der. L., Catherine $K$. and Charles, T. (2016). Sustainable growth in the Kenyan dairy sector: A quick scan for robustness, reliability and resilience. Report 3R Kenya/WLR 979.

6. United States Agency for International Development. USAID (2012). Final 
Performance Evaluation of the Kenyan Dairy Sector Competitiveness Program.

7. Kenya National Bureau of Statistics, KNBS. (2018). Economic survey.

8. Fengxia, D., Jing, L. and Allen, M. F. (2010). Effects of Credit Constraints on Productivity and Rural Household Income in China. Centre for Agricultural and Rural Development, Lowa State University. Working Paper 10-WP 516.

9. Ibrahim, A. and Bauer, S. (2013). Access to Microfinance and its Impact of Farm Profits among Rural Farmers in Dry land Sudan: Global Advanced Research Journal of Agricultural Sciences, vol. 2(3).

10. Foltz, D. (2004). Credit Market Access and Profitability in Tunisian Agriculture. Journal of Agricultural Economics, 30: 229 -240.

11. Nyangito, H. O., Nzuma, J., Ommeh, H. and Mbithi, M. (2004). Impacts of Agricultural Trade and related Policy Reforms on Food Security in Kenya. Kenya Institute for Public Policy Analysis (KIPPRA).

12. Wambugu, S., Kirimi, L. and Opiyo, J. (2011). Productivity Trends and the Performance of Dairy Sector in Kenya. Tegemeo institute of agricultural policy and development. https:/www.tegemeo.org.

13. Hemen, T. and Amah, T. (2015). Challenges Affecting Dairy Farmers in Kenya: A Case Study of Dairy Farmer Groups in Njabini, Nyandarua County.

14. Mugenda, O. M. and Mugenda, A.G. (1999). Research Methods: Quantitative and Qualitative Approaches. Nairobi, acts press.

15. Nassiuma, D. K. (2000). Survey sampling: Theory and methods. Njoro, Kenya: Egerton University Press.

16. Mburu, G. N. (2016). Factors affecting production of dairy products in Kenya: A case of co-operative societies in Kiambu County. Master thesis submitted to University of Nairobi.

17. Assogba P. N, Kokuye, S. E., Roseline, N., Djenontin, J. A., Pardoe, J. and Yabi, J. A. (2017). Determinants of credit access by smallholder farmers in North East Benin. Journal of Development and Agricultural Economics 9(8): 210-216.

18. Okunsola, A., Osuma, G. O. and Omankhanlen, E. A. (2019). Agricultural finance and economic growth: Evidence from Nigeria. Business theory and practice, 20: 467475

19. Ume, S. I., Ezeano, C. I. and Obiekwe, N. J. (2018). Analysis of the determinant factors to loan repayment among Broiler farmers in Enugu State, Nigeria. International Journal of Environmental and Agricultural Research 4(6).

20. Keider, A. (2000). "Determinants of Access to Credit and Loan Amount: Household Level Evidence from Ethiopia." Ethiopian Journal of Economics, 74(1).

21. Ehiakpor, D. S., Adzawle, W., Danso, A. G. (2016) Effects of access to agricultural credit on farm income in the Talensi District of
Northern Ghana. Research Journal of Agricultural Sciences 7 (55).

22. Akudugu, M. A. (2012). Estimation of the determinants of credit access and demand by farmers and supply by rural Banks in Ghanas Upper East region. Asian Journal of Agriculture and Rural Development. 2(2): 189200.

23. Fatoki, O. O. and Smit, A. V. (2011). Constraints to Credit Access by New SMEs in South Africa: A Supply Side Analysis. The African Journal of Business and Management, 5 (4): 1413-1425

24. Goshu, F. G. (2016). Determinants of Access to Credit and Credit Source Choice by Micro, Small and Medium Enterprises in Nekemte, Ethiopia. International Journal of African and Asian Studies, 28. 